\title{
Социально-психологическая модель ценностей различных поколений современного российского общества
}

\author{
Александр М. Рикель ${ }^{1 *}$, Светлана В. Доренская ${ }^{2}$ \\ ${ }^{1}$ Московский государственный университет имени М. В. Ломоносова, г. Москва, \\ Российская Федерация \\ 2 Психологический институт Российской академии образования, г. Москва, \\ Российская Федерация \\ ${ }^{*}$ E-mail: a.m.rikel@gmail.com
}

\begin{abstract}
Аннотация
Ввеление. Статья описывает исследование, целью которого выступи^о изучение особенностей ценностной иерархии различных поколений современной России. Акцентируется внимание на восприятии поколениями Аругих групп ^юАей и на их мнении о своей возрастной когорте. Объектом исслеАования яви^ись различные поколения современной России, а предметом - особенности их ценностей. Анализируются различные подходы к пониманию термина «поколение». Целью исследования выступило изучение ценностей различных поколений современной России. В этом смысле исслеАование являлось поисковым, его новизна - в построении моделей самовосприятия и взаимовосприятия современными российскими поколениями, основанных на ценностных Аиспозициях.
\end{abstract}

Методы. Методическим аппаратом эмпирического исследования выступили опросник «Ценностные ориентации» М. Рокича, авторская анкета на выявление представлений поколений о Аругих поколениях и авторский опросник на выяв^ение ценностей, которые Аекларируются культурой. В исслеАовании приняло участие 100 человек (40 мужчин и 60 женщин, рожАенных в промежутке межАу 1948 и 1997 гоАами).

Результаты. В результате статистического анализа была выявлена иерархия ценностей Аля кажАого из трех исследуемых поколений. Выявлены значимые различия в иерархиях и особенности взаимовосприятия поколений в зависимости от ценностных ориентаций. Обнаружено, что поколения, сорормировавшиеся в более отАаленные Аруг от Аруга промежутки, отличаются Аруг от Аруга в большей степени, а восприятие поколений Аруг Аруга смежно с теми ценностями у кажАой из групп респондентов, которые были продиктованы социумом.

ОбсужАение результатов. Результаты интерпретировались в рамках культурологической и социально-психологической основ становления поколенческих групп, описывающих «разрыв» трансмиссии ценностей межАу поколениями. Результаты 
подтвержАают ^огику К. Маннгейма, М. Мил и Э. Тодрфлера и последние исследования: ценностный межпоколенческий разрыв позволяет слелать прогноз об уменьшении возрастных рамок в рамках олной поколенческой когорты $\Delta о$ 10-15 ^ет. Ценностный разрыв базируется на взаимовосприятии поколений сквозь призму различий в базовых ценностях, отношения к семье, работе, материальным и общегражАанским ценностям. Эти ценности выступают основанием $\Delta \wedge я$ восприятия поколенческими группами Аруг Аруга.

\section{КАючевые слова}

общие ценности, ценностные ориентации, ценности поколений, поколение, социализация, инкультурация, типология поколений, иерархия ценностей, восприятие поколениями поколений

\section{Основные положения}

- в статье показано наличие значимого ценностного «разрыва» межАу представителями трех поколений, проживающих в современной России, что подтвержАवет как предылущие исследования, так и данные, получаемые в запалных странах;

- различия в ценностных ориентациях вкупе с представлениями о ценностях Аругих поколений обуславливают перцептивные особенности, позволяющие говорить о восприятии поколениями Аруг Аруга;

- на основании анализа восприятия поколениями ценностей иных поколенческих групп предлагаются пять перцептивных моделей, позволяющих выявить ценности, оказывающиеся знаковыми с точки зрения межпоколенческой коммуникации.

\section{Благодарности}

Статья выполнена при финансовой поддержке Российского фонда фундаментальных исследований (проект № 17-06-00980) «Историко-политические факторы трансформации коллективной памяти и идентичности российского общества».

\section{Для цитирования}

Рикель А. М., Доренская С. В. Социально-психологическая модель ценностей различных поколений современного российского общества // Российский психологический журнал. - 2017. - Т. 14, № 4. - С. 205-225.

Материалы статьи получены 17.04.2017 


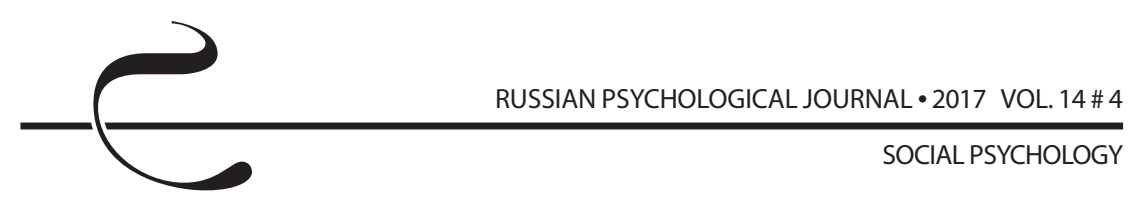

UDC 159.9.072.432:316.6

DOI: $10.21702 /$ rpj.2017.4.10

\title{
A Socio-Psychological Model of Values Among Different Generations in Modern Russian Society
}

\author{
Aleksandr M. Rikel'1" ${ }^{*}$, Svetlana V. Dorenskaya² \\ ${ }^{1}$ Lomonosov Moscow State University, Moscow, Russian Federation \\ 2 Psychological Institute, Russian Academy of Education, Moscow, Russian Federation \\ *Correspondence author. E-mail: a.m.rikel@gmail.com
}

\begin{abstract}
Introduction. The study (a) addresses value hierarchy among different generations in modern Russia and (b) concentrates on how different generations perceive other groups of people and also people of their own age cohort. Different generations of modern Russia were the object of the study; their values became the subject of the study. The paper provides an analysis of various approaches to understanding the "generation" term. The novelty of the research lies in constructing models of how modern Russian generations perceive themselves and each other on the basis of value dispositions.
\end{abstract}

Methods. These were M. Rokich's "Value Orientation" technique, the author's questionnaire for identifying how generations perceive each other, and the author's questionnaire for revealing values declared by culture. The study involved 100 people (40 men and 60 women born between 1948 and 1997).

Results. The statistical analysis revealed a hierarchy of values for each of the three studied generations. Significant differences in the hierarchies and mutual perception of generations depend on value orientations. Respondents with greater age difference differed the most. Generations perceived each other according to values declared by culture in each group of respondents.

Discussion. Cultural and socio-psychological fundamentals for the formation of generational groups, describing a generational "gap" in transmission of values, helped to interpret the results. The results confirmed the logic of K. Mannheim, M. Mead, E. Toffler, and also recent studies. The value intergenerational gap predicts reduction in age limits to 10-15 years within a single generational cohort. Differences in basic values, attitude to family, work, material and civic values determine how generations perceive each other and also the value gap. Generational groups perceive each other being guided by these values.

\section{Keywords}

common values, value orientations, values of generation, generation, socialization, inculturation, typology of generations, hierarchy of values, perception of generations 


\section{Highlights}

- The study revealed a significant value gap between the three generations living in modern Russia. Previous studies and the data obtained from Western countries confirm these findings.

- Differences in value orientations along with ideas about values among other generations determine perceptual features of how generations perceive each other. - Five perceptual models help to reveal values important in terms of intergenerational communication.

\section{Acknowledgments}

This work was supported by a grant from the Russian Foundation for Basic Research "Historical and Political Factors for the Transformation of Collective Memory and Identity in Russian Society" (project no. 17-06-00980).

\section{For citation}

Rikel' A. M., Dorenskaya S.V. A Socio-Psychological Model of Values Among Different Generations in Modern Russian Society. Rossiiskii psikhologicheskii zhurnal - Russian Psychological Journal, 2017, V. 14, no. 4, pp. 205-225 (in Russian).

Original manuscript received 17.04.2017

\section{Введение}

Термин «поколение» имеет междисциплинарную природу и может быть рассмотрен сквозь призму различных научных теорий. Данное понятие используется и анализируется в истории [1, 2], генетике [3, 4], социологии $[5,6]$, культурологии $[7,8]$ и других науках. Однако большинство авторов отличающихся подходов выделяет такие критерии, как (а) возрастные границы поколений и (б) их особенное социально-экономическое, культурное и ценностное психологическое пространство. В контексте нашего подхода термин «поколение» используется как общность людей, которые родились в определенный промежуток времени и социализировались в период одинаковых социально-экономических, политических и демографических условий, повлиявших на их глубинные представления, убеждения о мире. Схожая социальная среда их становления сформировала некую общую ценностную канву с повсеместной выраженностью некоторых ценностей и объединила индивидов в большую группу поколения естественным путем.

Так, именно социализация через процесс инкультурации выступает в качестве основного механизма формирования поколений, т. к. изменяющийся мир воздействует на становление личности человека и преломляет его психологическое пространство для синергии с окружающей социальной 


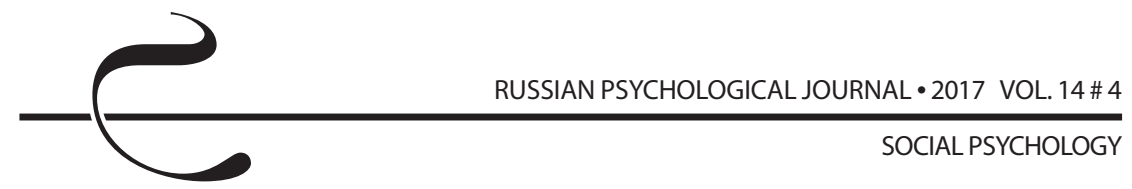

действительностью. Важное значение в социализации играет историческое развитие государства: в переломные моменты происходит сдвиг ценностно-смысловых установок общества $[9,10]$, которые, по мнению А. Н. Леонтьева [11], могут быть обозначены следующими основными признаками: общее число ценностей сравнительно невелико, все люди обладают одними и теми же ценностями, ценности организованы в системы, истоки человеческих ценностей прослеживаются в культуре, влияние ценностей прослеживается практически во всех социальных феноменах $[12,13,14$, $15,16,17]$. Новейшие исследования, связанные с быстротой изменений, происходящих в современном обществе, охватывают как изучение ценностных ориентаций отдельных молодежных групп [18, 19, 20, 21], так и профессиональных общностей, например, в диаде взаимодействия «преподаватель студент» [22] или «предприниматель - клиент» [23], или в контексте влияния СМИ и массовой культуры [24].

Для целей исследования, описываемого в данной статье, представляется крайне необходимым упомянуть взаимосвязи между возрастом и принадлежностью к тому или иному поколению. Причем поколение здесь рассматривается как та большая социальная группа, которая выступает значимым фактором формирования ценностных ориентаций. Как известно, социализация продолжительна, но протекает различно у детей, подростков и взрослых, причем у последних связана с изменением их поведения, что помогает им лучше адаптироваться в новых ситуациях и группах. В то же время, подростковая социализация - это во многом ассимиляция общих базовых ценностей и "духа времени», что делает ее роль более весомой в контексте нашего исследования.

Следует упомянуть о выделяемых в статье временных промежутках поколений: поколение 1943-1965 годов рождения, поколение 1965-1984 годов рождения и поколение 1984-2003 годов рождения. Стоит отметить, что данное разделение соответствует крупным этапам в истории СССР и России: переходу от социализма к стадии «застоя» и последующей научно-технической революции, изменению устоев жизни общества. Данные промежутки были выделены в статье отечественного социолога М. И. Исаевой [25]. При этом одним из исходных постулатов исследования было признание факта, что история является непрерывным процессом, и говорить о точных границах изменения социальных установок и представлений нет возможности; более того, ценности людей могут изменяться в более короткие временные интервалы, но, в свою очередь, выделение данных границ позволяет нам выявить различия в ценностях тех людей, которые уже личностно сформировались и составляют наиболее крупные возрастные когорты в современной России. 
В дополнение к этому, ценности семьи, профессионального успеха и другие, так называемые общие ценности, могут быть связаны с некоторыми возрастными аспектами развития и не отражать поколенческую специфику. В то же время нельзя не признать наличие ценностей (так называемых поколенческих), которые отражают тесную связь культуры и группы людей, рожденных в определенный исторический период.

С целью развести возрастные и поколенческие различия был проведен двухфазный анализ. Сначала было проведено теоретическое исследование ценностей, приписываемых определенному поколению, а после этого этапа была проведена экспертиза специалистами по истории, которые помогли провести дополнительную черту между данными типами ценностей.

Тем самым наше эмпирическое исследование было посвящено выявлению тех ценностей, которые присущи каждому из поколений в настоящее время, однако более важным вопросом для рассмотрения стало восприятие различными поколениями друг друга в контексте выявленных ценностей. Именно этот фокус представляет собой социально-психологический ракурс рассмотрения проблемы.

\section{Методы}

Выборка состояла из 100 человек (40 мужчин и 60 женщин), рожденных в промежутке между 1948 и 1997 годами и проживающих в различных городах России. Возраст респондентов варьировался от 20 до 67 лет.

В рамках выборки, исходя из целей исследования, уместнее выделить поколенческие группы: (1) 1948-1963 годы рождения - 31 человек, средний возраст 56,6; (2) 1965-1984 годы рождения - 34 человека, средний возраст 40,3; (3) 1986-1997 годы рождения - 35 человек, средний возраст 23,2.

Для достижения целей исследования мы использовали следующие методики:

1. Методика «Ценностные ориентации» М. Рокича, направленная на выявление иерархии ценностных ориентаций у индивида.

2. Авторская анкета на выявление представлений поколений о других поколениях и о своем поколении. Данная анкета включала в себя открытые вопросы с просьбой закончить утверждения о «типичном человеке», который родился в определенный момент времени, соответствующий одному из поколений. Использованными незаконченными утверждениями выступили: «Этот человек убежден, что...», «Смысл жизни этого человека заключается в...», «Этот человек стремится достичь в жизни...», «Этот человек ценит в жизни...».

3. Авторский опросник на выявление ченностей поколений, которые транслируются культурой. Данный опросник состоит из 19-ти ценностей, которые 
были выделены нами благодаря анализу исторической и культурологической литературы и раскрывают одно из 3-х поколений. Так, 7 ценностей (патриотизм, социальная полезность обществу, единение, оптимистическое отношение к жизни, уважение авторитета, принадлежность к своей нации, героизм) характерны для первого поколения 1943-1965 годов, 5 ценностей (высокое положение в обществе, космополитизм, стабильность, рациональность в принятии решений, критический взгляд на власть) - для следующего поколения 1965-1984 годов, и оставшиеся 7 ценностей (личный успех, индивидуальность, уважение различных точек зрения, материальное благополучие, разнообразие, независимость и доступ к информации) - для третьего поколения 1984-2003 годов. Данная методика была апробирована на 11-ти экспертах, которыми являлись студенты выпускного курса исторического факультета МГУ имени М. В. Ломоносова. Экспертам были предложены 24 ценности в случайном порядке, которые следовало отнести к одному из трех поколений.

Возможными ограничениями полученных результатов выступили размер выборки, а также демографические факторы (различия в полученных данных между мужчинами и женщинами и влияние места жительства не рассматривались).

\section{Результаты}

На первом этапе анализа результатов была рассмотрена выраженность ченностей у различных поколений, и выявлены значимые различия в их иерархии по трем группам респондентов. Для достижения данной цели мы использовали статистический критерий независимых выборок Манна - Уитни.

Таким образом, для первой поколенческой группы характерны следующие ценности, находящиеся на вершине их иерархии (см. таблицу 1): ценности патриотизма, единения и стабильности. Стоит отметить, что «патриотизм» и «единение» наиболее сильно выражены у людей, рожденных в промежутке 1943-1965 годов, а далее уже следуют «социальный порядок», «безопасность». Также для данной группы испытуемых важны ценности социальной полезности обществу, уважения различных точек зрения, принадлежности к своей нации. Наименее значимыми ценностными ориентациями выступили «индивидуальность», «высокое положение в обществе», «разнообразие», «космополитизм». Похожие результаты были получены и у второй группы респондентов: для поколения 1965-1984 годов характерны ценности социальной полезности обществу, патриотизма и героизма в наибольшей степени, а «независимость», «космополитизм» и «индивидуальность» - в наименьшей. Весьма интересную ценностную иерархию, радикально отличающуюся от первых двух групп испытуемых, имеет поколение 1984-2003 годов: так, самыми значимыми ценностями для него являются «космополитизм», 
«индивидуальность», «разнообразие», а самыми незначительными оказались социально направленные ценности принадлежности к своей нации, героизма, полезности обществу, единения и патриотизма.

Таблица 1. Выраженность (иерархия) поколенческих ценностей у разных поколений по среднему рангу критерия Манна - Уитни (средний ранг ияи н)

Table 1. Hierarchy of values among different generations by the Mann-Whitney $U$ test (means, $\mu$ )

\begin{tabular}{|c|c|c|c|}
\hline & $\begin{array}{c}\text { Поколение } \\
\text { 1943-1965 } \\
\text { Generation born in } \\
1943-1965\end{array}$ & \begin{tabular}{|c|} 
Поколение \\
1965-1984 \\
Generation born in \\
$1965-1984$
\end{tabular} & $\begin{array}{c}\text { Покомение } \\
\text { 1984-2003 } \\
\text { Generation born in } \\
1984-2003\end{array}$ \\
\hline 1. & $\begin{array}{c}\text { Патриотизм }(63,4) \\
\text { Patriotism }\end{array}$ & $\begin{array}{c}\text { Социальная полез- } \\
\text { ность обществу } \\
(60,7) \\
\text { Social usefulness }\end{array}$ & $\begin{array}{c}\text { Космополитизм } \\
(65,6) \\
\text { Cosmopolitanism }\end{array}$ \\
\hline 2. & $\begin{array}{c}\text { ЕАинение }(61,6) \\
\text { Unity }\end{array}$ & $\begin{array}{c}\text { Патриотизм }(60,2) \\
\text { Patriotism }\end{array}$ & $\begin{array}{c}\text { ИнАИВИАУवАьнОСТЬ } \\
(64,1) \\
\text { Individuality }\end{array}$ \\
\hline 3. & $\begin{array}{c}\text { Стабильность } \\
(55,7) \\
\text { Stability }\end{array}$ & $\begin{array}{c}\text { Героизм }(59,4) \\
\text { Heroism }\end{array}$ & $\begin{array}{c}\text { Разнообразие } \\
(62,7) \\
\text { Diversity }\end{array}$ \\
\hline$\ldots$ & & & \\
\hline 17. & $\begin{array}{c}\text { Высокое положе- } \\
\text { ние в обществе } \\
(41,9) \\
\text { High position in } \\
\text { society }\end{array}$ & $\begin{array}{c}\text { Независимость } \\
(44,9) \\
\text { Independence }\end{array}$ & $\begin{array}{c}\text { Социальная полез- } \\
\text { ность обществу } \\
(36,9) \\
\text { Social usefulness }\end{array}$ \\
\hline 18. & $\begin{array}{c}\text { Разнообразие } \\
(41,6) \\
\text { Diversity }\end{array}$ & $\begin{array}{c}\text { Космополитизм } \\
(44,6) \\
\text { Cosmopolitanism }\end{array}$ & $\begin{array}{c}\text { ЕАинение }(33,2) \\
\text { Unity }\end{array}$ \\
\hline 19. & $\begin{array}{c}\text { Космополитизм } \\
(39,2) \\
\text { Cosmopolitanism }\end{array}$ & $\begin{array}{c}\text { ИнАИВИАУवАьнОСть } \\
(43,9) \\
\text { Individuality }\end{array}$ & $\begin{array}{c}\text { Патриотизм }(29,6) \\
\text { Patriotism }\end{array}$ \\
\hline
\end{tabular}

На второй стадии нашего исследования была проанализирована иерархия общих ценностей у представителей различных поколений. 
Таблица 2. Выраженность (иерархия) общих ценностей у разных поколений по среднему рангу критерия Манна - Уитни (средний ранг или $\mu$ )

Table 2. Hierarchy of common values among different generations by the MannWhitney $U$ test (means, $\mu$ )

\begin{tabular}{|c|c|c|c|}
\hline & \begin{tabular}{|c|} 
Покомение \\
$1943-1965$ \\
Generation born in \\
$1943-1965$
\end{tabular} & $\begin{array}{c}\text { Поколение } \\
\text { 1965-1984 } \\
\text { Generation born in } \\
1965-1984\end{array}$ & \begin{tabular}{|c|} 
Поколение \\
1984-2003 \\
Generation born in \\
$1984-2003$
\end{tabular} \\
\hline 1. & $\begin{array}{l}\text { 3aоpoвbe (38) } \\
\text { Health }\end{array}$ & $\begin{array}{l}\text { Интересная } \\
\text { работа (41) } \\
\text { Interesting job }\end{array}$ & $\begin{array}{l}\text { Познание }(32,1) \\
\text { Knowledge }\end{array}$ \\
\hline 2. & $\begin{array}{c}\text { Счастье Аругих } \\
(40,4) \\
\text { Happiness of others }\end{array}$ & $\begin{array}{c}\text { Счастливая се- } \\
\text { мейная жизнь } \\
(41,8) \\
\text { Happy family life }\end{array}$ & $\begin{array}{c}\text { Широта взгАяАОВ } \\
(39,3) \\
\text { Breadth of views }\end{array}$ \\
\hline 3. & $\begin{array}{c}\text { Aккуратность (42) } \\
\text { Aсcuracy }\end{array}$ & $\begin{array}{c}\text { Ответственность } \\
(41,9) \\
\text { Responsibility }\end{array}$ & $\begin{array}{c}\text { УАовольствия } \\
(41,4) \\
\text { Pleasure }\end{array}$ \\
\hline \multicolumn{4}{|l|}{$\ldots$} \\
\hline 34. & $\begin{array}{c}\text { Интересная рабо- } \\
\text { та }(58,9) \\
\text { Interesting job }\end{array}$ & $\begin{array}{c}\text { Широта взгАяАОВ } \\
(58,4) \\
\text { Breadth of views }\end{array}$ & $\begin{array}{c}\text { Счастье Аругих } \\
\text { (62) } \\
\text { Happiness of others }\end{array}$ \\
\hline 35. & $\begin{array}{c}\text { ТверАая воля } \\
(61,37) \\
\text { Strong will }\end{array}$ & $\begin{array}{c}\text { Красота природы } \\
\text { и искусства }(59,5) \\
\text { Beauty of nature } \\
\text { and art }\end{array}$ & $\begin{array}{c}\text { Счастливая се- } \\
\text { мейная жизнь } \\
(63,3) \\
\text { Happy family life }\end{array}$ \\
\hline 36. & 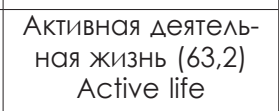 & $\begin{array}{l}\text { Познание }(62,5) \\
\text { Knowledge }\end{array}$ & $\begin{array}{l}\text { 3Аоровье }(64,4) \\
\text { Health }\end{array}$ \\
\hline
\end{tabular}

Для старшего поколения самыми значимыми ценностями являются «здоровье», «счастье других», «аккуратность», «исполнительность», «красота природы и искусства», а в конце списка расположены ценности активной деятельной жизни, твердой воли, интересной работы, образованности и познания (см. таблицу 2). В то же время, для следующего поколения, наоборот, ценность работы является важной в жизненном поле респондента, а также такие актуальные для этого возраста людей ценности, как «счастливая семейная жизнь», «ответственность», «материально обеспеченная жизнь», «смелость в отстаивании своего мнения». Как и для поколения 1943-1965 годов, данная группа респондентов располагает ценность познания в самом конце своей иерархии наряду с ценностями красоты природы и искусства, широты 
взглядов, самоконтроля и удовольствия. Поколение 1984-2003 годов, в свою очередь, «переворачивает» ценности первого и второго поколений некоторым образом и воспринимает ценности здоровья, счастливой семейной жизни, счастья других, аккуратности и материально обеспеченной жизни как самые неважные для себя, а наиболее значимыми считает ценности познания, широты взглядов, удовольствия, жизненной мудрости и развития.

На третьем этапе анализа было рассмотрено восприятие поколениями друг друга, а также мнение о превалирующих ценностях той группы людей, к которой относятся сами респонденты. Стоит отметить, что данные были получены благодаря контент-анализу свободных ответов испытуемых, а ценности в таблицах, представленные ниже, расположены по количеству их упоминаний и являются самыми часто встречающимися, исходя из мнения опрашиваемых.

Таблица 3. Восприятие ценностей поколения 1943-1965 годов различными группами испытуемых

Table 3. Values of the generation born in 1943-1965 in perceptions of different groups of respondents

\begin{tabular}{|c|c|c|}
\hline \multicolumn{3}{|c|}{$\begin{array}{l}\text { Покомение 1943-1965 } \\
\text { Seneration born in 1943-1965 }\end{array}$} \\
\hline $\begin{array}{c}\text { Ценности (мнение о сво- } \\
\text { ем поколении) } \\
\text { Values (ideas about } \\
\text { respondent's own } \\
\text { generation) }\end{array}$ & $\begin{array}{c}\text { Ценности (мнение поко- } \\
\text { мения 1965-1984) } \\
\text { Values (idea of the } \\
\text { generation born in } \\
\text { 1965-1984) }\end{array}$ & $\begin{array}{c}\text { Ценности (мнение поко- } \\
\text { мения 1984-2003) } \\
\text { Values (idea of the } \\
\text { generation born in } \\
\text { 1984-2003) }\end{array}$ \\
\hline $\begin{array}{l}\text { Безопасность } \\
\text { Safety }\end{array}$ & $\begin{array}{l}\text { Семья } \\
\text { Family }\end{array}$ & $\begin{array}{l}\text { Семья } \\
\text { Family }\end{array}$ \\
\hline $\begin{array}{l}\text { Семья } \\
\text { Family }\end{array}$ & $\begin{array}{l}\text { EАинение } \\
\text { Unity }\end{array}$ & $\begin{array}{l}\text { Мир, безопасность } \\
\text { Peace, security }\end{array}$ \\
\hline $\begin{array}{l}\text { Paбота, труд } \\
\text { Work }\end{array}$ & $\begin{array}{l}\text { Pабота, труд } \\
\text { Work }\end{array}$ & $\begin{array}{l}\text { Pабота, труд } \\
\text { Work }\end{array}$ \\
\hline $\begin{array}{l}\text { Патриотизм } \\
\text { Patriotism }\end{array}$ & $\begin{array}{l}\text { Мир, безопасность } \\
\text { Peace, security }\end{array}$ & $\begin{array}{c}\text { Социальная полезность } \\
\text { обществу } \\
\text { Social usefulness }\end{array}$ \\
\hline $\begin{array}{l}\text { Eдинение } \\
\text { Unity }\end{array}$ & $\begin{array}{l}\text { Оптимизм } \\
\text { Optimism }\end{array}$ & $\begin{array}{l}\text { Традиции } \\
\text { Traditions }\end{array}$ \\
\hline $\begin{array}{c}\text { Социальная полезность } \\
\text { обществу } \\
\text { Social usefulness }\end{array}$ & $\begin{array}{l}\text { Уважение } \\
\text { Respect }\end{array}$ & $\begin{array}{c}\text { Елинение } \\
\text { Unity }\end{array}$ \\
\hline $\begin{array}{c}\text { Уважение } \\
\text { Respect }\end{array}$ & $\begin{array}{c}\text { Патриотизм } \\
\text { Patriotism }\end{array}$ & $\begin{array}{l}\text { Честность } \\
\text { Honesty }\end{array}$ \\
\hline
\end{tabular}


Поколение 1943-1965 считает, что во главе иерархии своего же поколения располагаются ценности безопасности, семьи, труда, патриотизма, единения, социальной полезности обществу и уважения (см. таблицу 3). Интересен тот факт, что поколение 1965-1984 годов и поколение 1984-2003 годов также рассматривают данные ценности как наиболее важные для самой старшей группы людей, однако среднее поколение включает в данную иерархию «оптимизм» и «уважение», а самая молодая группа - «традиции» и «честность».

Таблица 4. Восприятие ценностей поколения 1965-1984 годов различными группами испытуемых

Table 4. Values of the generation born in 1965-1984 in perceptions of different groups of respondents

\begin{tabular}{|c|c|c|}
\hline \multicolumn{3}{|c|}{$\begin{array}{c}\text { Покомение 1965-1984 } \\
\text { Generation born in 1965-1984 }\end{array}$} \\
\hline $\begin{array}{c}\text { Ценности (мнение о сво- } \\
\text { ем поколении) }\end{array}$ & $\begin{array}{c}\text { Ценности (мнение поко- } \\
\text { ления 1943-1965) }\end{array}$ & $\begin{array}{c}\text { Ценности (мнение поко- } \\
\text { ления 1984-2003) }\end{array}$ \\
\hline $\begin{array}{l}\text { Values (ideas about } \\
\text { respondent's own } \\
\text { generation) }\end{array}$ & $\begin{array}{c}\text { Values (idea of the } \\
\text { generation born in } \\
\text { 1943-1965) }\end{array}$ & $\begin{array}{c}\text { Values (idea of the } \\
\text { generation born in } \\
\text { 1984-2003) }\end{array}$ \\
\hline $\begin{array}{l}\text { Хорошее образование } \\
\text { Good education }\end{array}$ & $\begin{array}{l}\text { Аеньги } \\
\text { Money }\end{array}$ & $\begin{array}{l}\text { Cемья } \\
\text { Family }\end{array}$ \\
\hline $\begin{array}{l}\text { Cembя } \\
\text { Family }\end{array}$ & $\begin{array}{l}\text { Новизна } \\
\text { Novelty }\end{array}$ & $\begin{array}{l}\text { Аостижение } \\
\text { Achievement }\end{array}$ \\
\hline $\begin{array}{l}\text { Аеньги } \\
\text { Money }\end{array}$ & $\begin{array}{l}\text { Социальный статус } \\
\text { Social status }\end{array}$ & $\begin{array}{l}\text { Аеньги } \\
\text { Money }\end{array}$ \\
\hline $\begin{array}{l}\text { Аостижение } \\
\text { Achievement }\end{array}$ & $\begin{array}{l}\text { Семья } \\
\text { Family }\end{array}$ & $\begin{array}{l}\text { Paбota } \\
\text { Work }\end{array}$ \\
\hline $\begin{array}{l}\text { Новизна } \\
\text { Novelty }\end{array}$ & $\begin{array}{l}\text { Аостижение } \\
\text { Achievement }\end{array}$ & $\begin{array}{l}\text { Новизна } \\
\text { Novelty }\end{array}$ \\
\hline $\begin{array}{l}\text { Интересная работа } \\
\text { Interesting job }\end{array}$ & $\begin{array}{l}\text { Образование } \\
\text { Education }\end{array}$ & $\begin{array}{l}\text { ИнАИвИАуальность } \\
\text { Individuality }\end{array}$ \\
\hline $\begin{array}{l}\text { Стабильность } \\
\text { Stability }\end{array}$ & $\begin{array}{l}\text { Патриотизм } \\
\text { Patriotism }\end{array}$ & $\begin{array}{l}\text { Стабильность } \\
\text { Stability }\end{array}$ \\
\hline
\end{tabular}

Следующее поколение, 1965-1984 годов, утверждает, что для их ровесников значимы ценности хорошего образования, семьи, материального достатка, достижения, новизны, интересной работы и стабильности (см. таблицу 4). Полученные результаты весьма интересны в сравнении с той иерархией, которая была выявлена при рассмотрении поколенческих ценностей: так, при анализе этой методики можно было сделать вывод о том, что для данной группы людей наиболее важны «социальная полезность обществу», «патриотизм» и «героизм», что несколько расходится с восприятием поколения близкой им 
общности людей. В свою очередь, по мнению поколения 1943-1965 годов, группа, рожденная в эпоху «застоя», ценит в жизни деньги, новизну, социальный статус, семью, достижение, образование и патриотизм, что схоже с результатами контент-анализа ответов поколения 1984-2003 годов, однако в его восприятии появляется также такая ценность, как «индивидуальность».

Таблица 5. Восприятие ценностей поколения 1984-2003 голов различными группами испытуемых

Table 5. Values of the generation born in 1984-2003 in perceptions of different groups of respondents

\begin{tabular}{|c|c|c|c|}
\hline & $\begin{array}{r}\Pi \\
\text { Gene }\end{array}$ & $\begin{array}{l}\text { околение 1984-2003 } \\
\text { ration born in 1984-2 }\end{array}$ & \\
\hline & $\begin{array}{c}\text { Ценности (мнение } \\
\text { о своем поколении) } \\
\text { Values (ideas about } \\
\text { respondent's own } \\
\text { generation) }\end{array}$ & $\begin{array}{c}\text { Ценности (мне- } \\
\text { ние поколения } \\
\text { 1943-1965) } \\
\text { Values (idea of the } \\
\text { generation born in } \\
\text { 1943-1965) }\end{array}$ & $\begin{array}{c}\text { Ценности (мне- } \\
\text { ние поколения } \\
\text { 1965-1984) } \\
\text { Values (idea of the } \\
\text { generation born in } \\
\text { 1965-1984) }\end{array}$ \\
\hline 1. & $\begin{array}{l}\text { Аеньги } \\
\text { Money }\end{array}$ & $\begin{array}{l}\text { Аеньги } \\
\text { Money }\end{array}$ & $\begin{array}{l}\text { Аеньги } \\
\text { Money }\end{array}$ \\
\hline 2. & $\begin{array}{l}\text { УАовольствия } \\
\text { Pleasure }\end{array}$ & $\begin{array}{l}\text { Caмореализация } \\
\text { Self-realization }\end{array}$ & $\begin{array}{l}\text { УАовольствия } \\
\text { Pleasure }\end{array}$ \\
\hline 3. & $\begin{array}{c}\text { Уверенность в себе } \\
\text { Self-reliance }\end{array}$ & $\begin{array}{l}\text { Семья } \\
\text { Family }\end{array}$ & $\begin{array}{l}\text { Paбота } \\
\text { Work }\end{array}$ \\
\hline 4. & $\begin{array}{l}\text { Аостижение } \\
\text { Achievement }\end{array}$ & 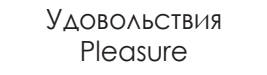 & $\begin{array}{l}\text { Аружба } \\
\text { Friendship }\end{array}$ \\
\hline 5. & $\begin{array}{l}\text { Аюбовь } \\
\text { Love }\end{array}$ & $\begin{array}{l}\text { Paбота } \\
\text { Work }\end{array}$ & $\begin{array}{c}\text { Образованность } \\
\text { Education }\end{array}$ \\
\hline 6. & $\begin{array}{l}\text { Социальное } \\
\text { положение } \\
\text { Social status }\end{array}$ & $\begin{array}{c}\text { ИнАИвиАуальность } \\
\text { Individuality }\end{array}$ & $\begin{array}{c}\text { Стабильность } \\
\text { Stability }\end{array}$ \\
\hline 7. & $\begin{array}{c}\text { Самодетерминация } \\
\text { (поиск своего места } \\
\text { в жизни) } \\
\text { Self-determination } \\
\text { (finding a place in life) }\end{array}$ & $\begin{array}{l}\text { Оптимизм } \\
\text { Optimism }\end{array}$ & $\begin{array}{c}\text { Уверенность } \\
\text { в себе } \\
\text { Self-reliance }\end{array}$ \\
\hline
\end{tabular}

В данном случае можно отметить тот факт, что все три поколения выдвигают ценность материального благополучия и денег на первое место для поколения 1984-2003 годов (см. таблицу 5), однако, с другой стороны, ни опросник М. Рокича, ни методика исследования поколенческих ценностей не выявили подобных тенденций для данной группы людей. 
Также для молодого поколения, по его же мнению, характерны ценности удовольствия, уверенности в себе, достижения, любви, социального положения и самодетерминации, поиска себя. Похожие выводы можно сделать посредством изучения восприятия двух других поколений, однако группа людей, рожденных в 1943-1965 годах, добавляет в список ценности работы, индивидуальности и оптимизма, а следующее поколение - дружбу, образованность и стабильность.

\section{Обсуждение результатов}

В рамках исследования были построены модели восприятия поколениями друг друга. Каждые из исследуемых поколений были взяты попарно, далее были сопоставлены декларируемые ими для своего поколения ценности (интегративно по тесту М. Рокича, по анкете «поколенческих ценностей» и по анкете с незавершенными предложениями) и воспринимаемые ими ценности других поколений. Значимая взаимосвязь между данными конструктами служила основанием для строительства модели (см. рисунок 1).

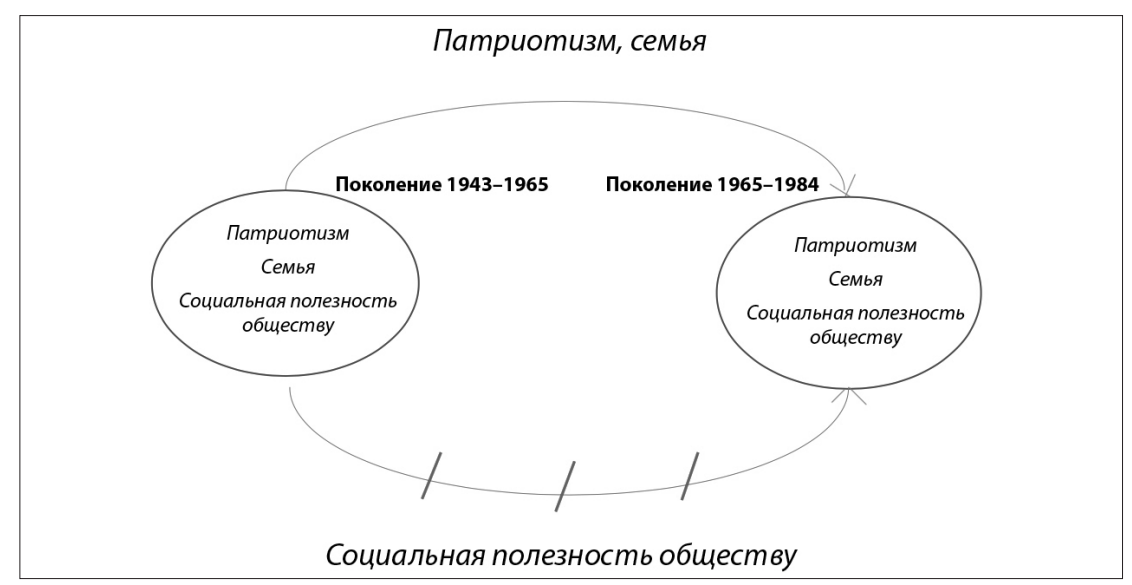

Рисунок 1. Молель восприятия поколением 1943-1965 поколения 1965-1984

Figure 1. The model showing how the generation born in 1943-1965 perceives the generation born in 1965-1984

В итоге, значимая для поколения 1943-1965 годов ценность патриотизма приписывается и следующему поколению. Стоит отметить, что социальная полезность обществу не появляется в восприятии старшим поколением другой группы респондентов, однако она характерна и для него, и для поколения 1965-1984 годов. 


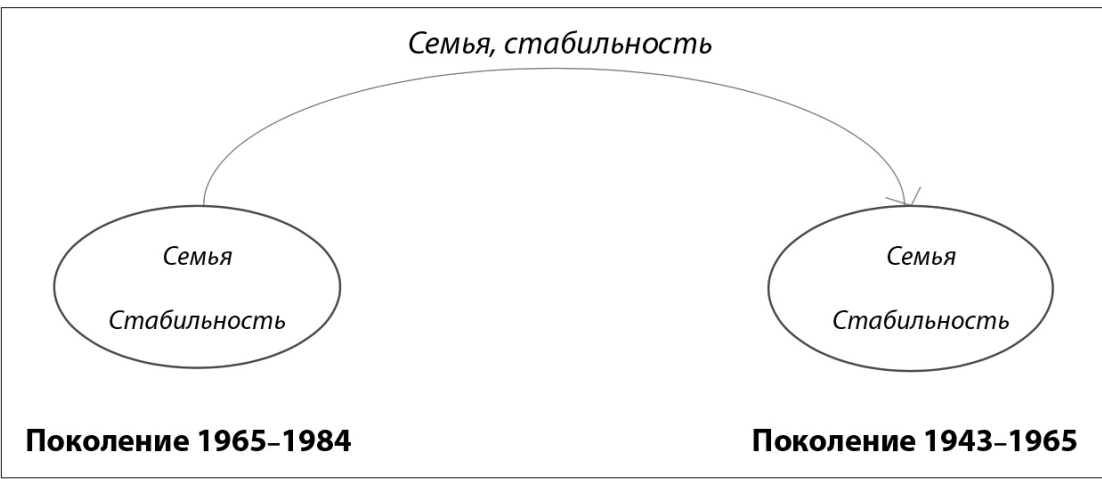

Рисунок 2. Молель восприятия поколением 1965-1984 поколения 1943-1965

Figure 2. The model showing how the generation born in 1965-1984 perceives the generation born in 1943-1965

Поколение 1965-1984 годов, в свою очередь, воспринимает старшее поколение сквозь призму таких ценностей, как стабильность и семья, что отражается в психологическом пространстве последнего в том числе (см. рисунок 2). По нашему мнению, появляющаяся в данном случае ценность семьи относится к возрастным особенностям обоих поколений, однако ценности патриотизма, социальной полезности общества и стабильности могут рассматриваться как транслируемые старшим поколением, либо как отдельно сформированные посредством культурного воздействия убеждения о мире.

Стоит отметить, что поколение 1965-1984 годов считается «эпохой застоя», при которой старые ценности нивелировались, а новые еще не сформировались. В данном случае можно предположить, что данное поколение в качестве некой опоры для построения мировоззрения сохраняет передаваемые им ценности поколения 1943-1965 годов. Однако если мы обратимся к таблице 4, показывающей мнение поколения 1965-1984 годов о своей когорте, то можно отметить факт того, что для этой группы людей важны несколько другие ценности: хорошее образование, семья, материальное благополучие.

В данном случае поколение 1965-1984 годов воспринимает поколение 1984-2003 годов сквозь призму таких ценностей, как «работа», «семья», «стабильность», а последнее, в свою очередь, приписывает старшей группе людей ценности денег и достижений (см. рисунки 3-5). Интересен тот факт, что и для одной, и для другой когорты данные ценности не отражаются в структуре их иерархии ценностей как наиболее значимые. Тем самым, можно предложить, что самое младшее поколение отдалено от предшествующего ему поколения 
в большей степени, чем поколение 1965-1984 годов от поколения 1943-1965. Полученные данные могут быть связаны с бо́льшим изменением устоявшихся культурных паттернов при сравнении культуры середины и конца XX в. Так, коммунистический уклад поколения 1943-1965 в итоге сменился на более индивидуалистическое мировоззрение, при котором ценности достижения, личного успеха и независимости играют важную роль.

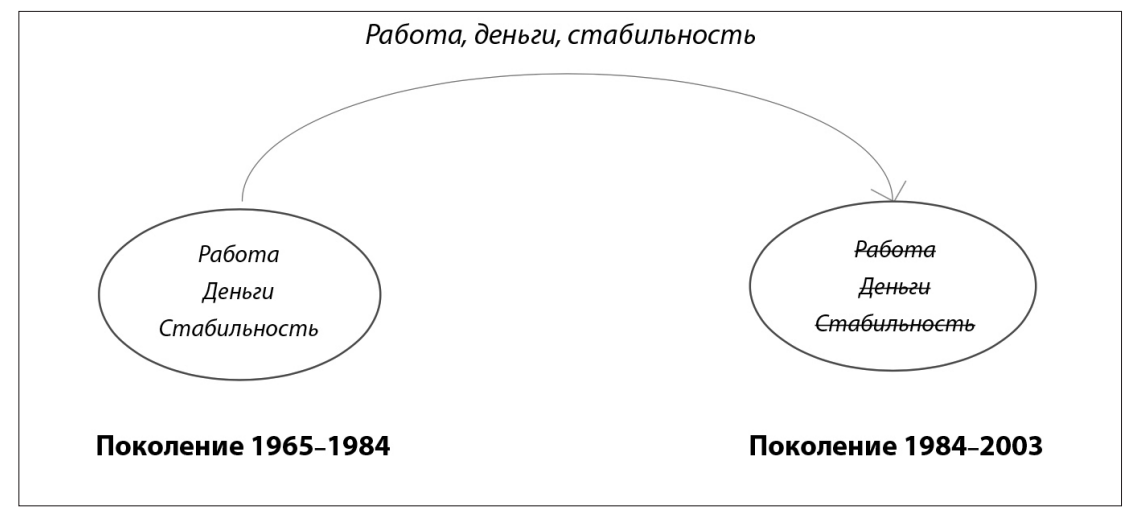

Рисунок 3. Молель восприятия поколением 1965-1984 поколения 1984-2003

Figure 3. The model showing how the generation born in 1965-1984 perceives the generation born in 1984-2003

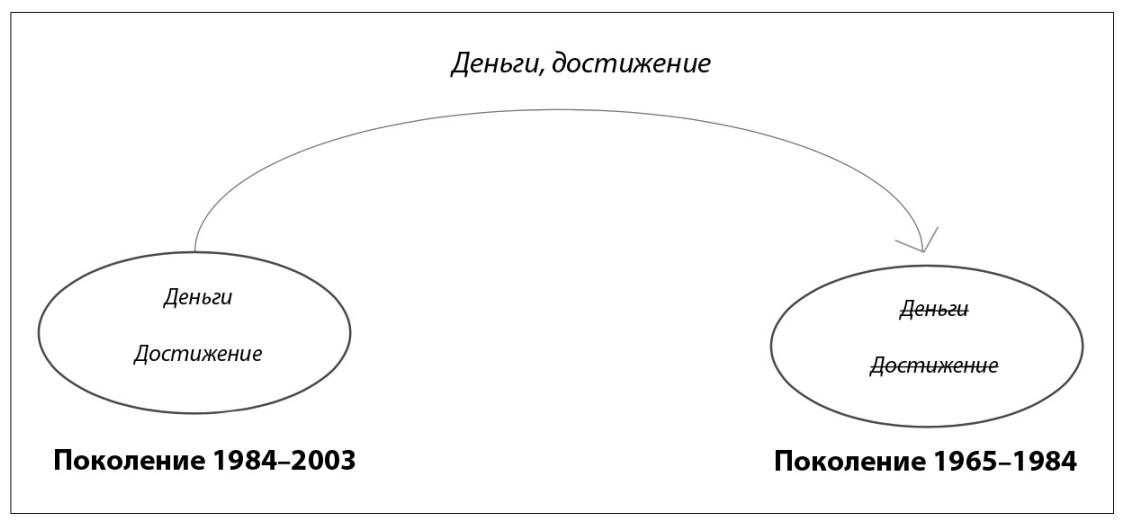

Рисунок 4. Молель восприятия поколением 1984-2003 поколения 1965-1984

Figure 4. The model showing how the generation born in 1984-2003 perceives the generation born in 1965-1984 
Следующим шагом выступило выявление общих ценностей для крайних групп респондентов, т. е. для поколения 1943-1965 и поколения 1984-2003.

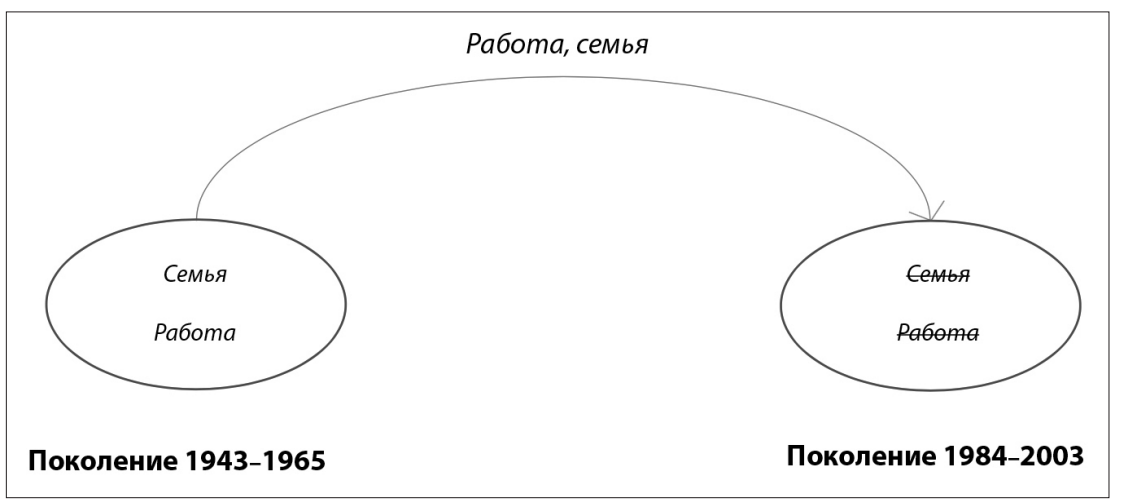

Рисунок 5. Молель восприятия поколением 1943-1965 поколения 1984-2003

Figure 5. The model showing how the generation born in 1943-1965 perceives the generation born in 1984-2003

Интересен тот факт, что в восприятии поколением 1984-2003 годов самого старшего поколения не было выявлено объединенных в сознании людей ценностей между этими двумя группами.

Стоит отметить, что для данных двух групп респондентов, которые представляют крайние возрасты в нашем исследовании, иерархия ценностей является практически противоположной, а в представлении этих когорт друг о друге не проявляются специфичные поколенческие ценности, декларируемые культурой. Тем самым, мы можем предположить, что между поколением 1943-1965 и поколением 1984-2003 годов не происходит не только трансляция ценностей от старшей группы к младшей, но также и культурная среда второго поколения практически не изменила иерархию поколения 1943-1965 годов с течением времени; это нельзя сказать о поколении 1965-1984 годов, некоторым образом совмещающем в себе ценности старшей группы и поколения 1984-2003 годов, которые, однако, в данном случае мы обозначим как ценностные ориентации.

\section{Выводы}

В данной статье были рассмотрены особенности ценностей различных поколений современной России, а также было проанализировано взаимное восприятие этими поколениями друг друга. Особое внимание было уделено культурологической подоплеке становления той или иной возрастной группы 


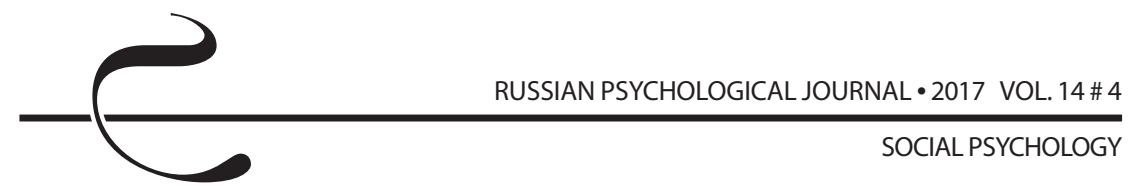

людей, которая, так или иначе, «разрывает» трансляцию ценностей между поколениями благодаря ключевым изменениям общественного порядка, произошедшим за последние 70 лет. Полученная в данном исследовании феноменология соотносится с классическими социально-психологическими и культурологическими [26] концепциями, описывающими изменяющийся характер взаимоотношений в рамках поколений. Так, Маргарет Мид говорила о префигуративном типе культуры, при котором классический способ трансляции ценностей и знаний (от родителей к детям) нарушается до прямо противоположного, а Элвин Тоффлер, рассуждая о появлении нового информационного общества, заявлял о появлении большого количества социальных конфликтов, связанных с резким убыстрением темпов жизни и так называемым футурошоком.

При этом полученный в данном исследовании на российской выборке результат (нарушение передачи ценностного опыта между «отцами и детьми») дополняет полученные в предыдущих международных исследованиях данные: ценностный межпоколенческий разрыв фиксируется в недавних американских, европейских и китайских $[27,28,29]$ исследованиях. Опасным сигналом для современного общества и важным предметом дальнейших научных исследований может служить увеличивающийся характер ценностного межпоколенческого разрыва, наличие которого позволяет ряду исследователей заявлять об уменьшении возрастных рамок в рамках одной поколенческой когорты до 10 лет (поколения X, Y, Z и пр.) [30].

Дальнейшее изучение данного феномена самоценно в социальной психологии при обращении к проблеме коллективной памяти, атрибуции и изучении социального поведения.

\section{Литература}

1. Бердяев Н. А. Русская идея. - М. : АСТ ; Полиграфиздат, 2010. - 287 с.

2. Ключевский В. О. Евгений Онегин и его предки // Ключевский В. О. Соч. : в 9 т. / под ред. В. Л. Янина. - М. : Мысль, 1990. - Т. 9. - С. 84-101.

3. Элиас Н. О процессе цивилизации. Социогенетические и психогенетические исследования. Т. 1. Изменения в поведении высшего слоя мирян в странах Запада. - М. ; СПб. : Университетская книга, 2001. - 332 с.

4. Иванов В. А. Генетика. - М. : Академкнига, 2006. - 643 с.

5. Левада Ю. А. Сочинения: избранное: социологические очерки, 2000-2005 / сост. Т. В. Левада. - М. : Издатель Карпов Е. В., 2011. - 507 с.

6. Глотов М.Б. Поколение как категория социологии // Социологические исследования. - 2004. - № 10. - С. 42-49.

7. Миронов В. В. Философия и метаморфозы культуры. - М. : Современные тетради, 2005. -424 с. 
8. Багдасарьян Н. Г. Культурология. - М. : Высшая школа, 2001. - 3-е изд., испр. и доп. - 511 с.

9. Пищик В. И. Поколения: социально-психологический анализ ментальности // Социальная психология и общество. - 2011. - № 2. - С. 80-88.

10. Strauss W., Howe N. The Fourth Turning: An American Prophecy What the Cycles of History Tell Us About America's Next Rendezvous with Destiny. N.Y. : Broadway Books, 1997. - 400 p.

11. Леонтьев А. Н. Лекции по общей психологии : Учеб. пособие для вузов по спец. «Психология» / под ред. Д. А. Леонтьева, Е. Е. Соколовой. - М. : Смысл, 2000. - 509 с.

12. Van Hiel A., Mervielde I., De Fruyt F. Stagnation and Generativity: Structure, Validity and Differential Relationships With Adaptive and Maladaptive Personality // Journal of Personality. - 2006. - Vol. 74, Issue 2. - P. 543-574. DOI: 10.1111/j.1467-6494.2006.00384.x

13. Twenge J. M., Campbell S. M. Generational differences in psychological traits and their impact on the workplace // Journal of Managerial Psychology. 2009. - Vol. 23, Issue 8. - P. 862-877. - DOI: 10.1108/02683940810904367

14. Gilleard C., Higgs P. Contexts of ageing: class, cohort and community. - Cambridge : Polity Press, 2005. - 224 p.

15. Андреева Г. М. Социальная психология. - М. : Аспект Пресс, 2001. - 384 с.

16. Емельянова Т. П. Феномен коллективных чувств в психологии больших социальных групп // Институт психологии Российской академии наук. Социальная и экономическая психология. - 2016. - T. 1, № 1. - URL: http:// soc-econom-psychology.ru/engine/documents/document195.pdf (дата обращения 16.01.2017).

17. МидМ. Культура и мир детства / под ред. И. С. Кона. - М. : Наука, 1988. - 429 с.

18. Сочивко Д. В. Проблема дробности межпоколенческой социальной отчужденности молодежи в современной России // Мир психологии. 2009. - № 3 (59). - С. 185-194.

19. Зернов Д. В. Романтические и пессимистические тенденции в ценностных ориентирах молодежи разных поколений // Вестник Нижегородского университета им. Н. И. Лобачевского. - 2014. - № 2 (34). - С. 47-53.

20. Лисовский В. Т. Духовный мир и ценностные ориентации молодежи России. - СПб. : Изд-во СПбГУП, 2000. - 508 с.

21. Пищик В. И., Гаврилова А. В., Сиврикова Н. В. Стили межпоколенного педагогического взаимодействия преподавателей и студентов разных поколенческих групп // Российский психологический журнал. - 2016. Т. 13, № 3. - С. 245-264.

22. Реан А. А. Семья в структуре ценностей молодежи // Российский психологический журнал. - 2017. - Т. 14, № 1. - С. 62-78. 
23. Позняков В. П., Никуло Е. А. Ценностные ориентации предпринимателей с разным уровнем ответственного отношения к участникам делового взаимодействия // Психологический журнал. - 2016. - Т. 37, № 1. - С. 79-88.

24. Рикель А. М., Тычинина М. И. Межпоколенные различия стратегий межличностных отношений // Психологические исследования. - 2017. - Т. 10, № 51. - C. 9. - URL: http://psystudy.ru (дата обращения: 01.10.2017).

25. Исаева М. И. Поколения кризиса и подъема в теории В. Штрауса и Н. Хоува // Знание. Понимание. Умение. - 2011. - № 3. - С. 290-295.

26. Тоффрлер Э. Шок будущего. - М. : АСТ, 2008. - 560 с.

27. Inglehart R., Welzel Ch. Modernization, Cultural Change, and Democracy: The Human Development Sequence. - Cambridge : Cambridge University Press, 2005. - $344 \mathrm{p}$.

28. Sun J., Wang $X$. Value differences between generations in China: a study in Shanghai // Journal of Youth Studies. - 2010. - Vol. 13, № 1. - P. 65-81.

29. Tsunokai G., Ksopowa A., Adams M. Racial preferences in Internet Dating: a comparison of four birth cohorts // The Western Journal of Black Studies. - 2009. - Vol. 33, № 1. - P. 1-15.

30. Howe N., Strauss W. Generations: The History of America's Future, 1584 to 2069. - New York : William Morrow \& Company, 1991. - 538 p.

\section{References}

1. Berdyaev N. A. Russkaya ideya [Russian idea]. Moscow, Poligrafizdat Publ., 2010. 287 p.

2. Klyuchevskii V. O. Eugene Onegin and his forefathers. In: Soch.: v 9 t. [Works: in 9 volumes]. Moscow, Mysl' Publ., 1990, V. 9, pp. 84-101.

3. Elias N. O protsesse tsivilizatsii. Sotsiogeneticheskie i psikhogeneticheskie issledovaniya. T. 1. Izmeneniya $v$ povedenii vysshego sloya miryan v stranakh Zapada [The civilizing process: Sociogenetic and psychogenetic investigations. V. 1: Changes in the behaviour of the secular upper classes in the West]. Moscow, Universitetskaya kniga Publ., 2001. 332 p.

4. Ivanov V. A. Genetika [Genetics]. Moscow, Akademkniga Publ., 2006. 643 p.

5. Levada Yu. A. Sochineniya: izbrannoe: sotsiologicheskie ocherki, 2000-2005 [Selected works: sociological essays, 2000-2005]. Moscow, Karpov E.V. Publ., 2011. 507 p.

6. Glotov M. B. Generation as a sociological category. Sotsiologicheskie issledovaniya - Sociological Studies, 2004, no. 10, pp. $42-49$ (in Russian).

7. Mironov V.V. Filosofiya imetamorfozy kul'tury [Philosophy and metamorphoses of culture]. Moscow, Sovremennye tetradi Publ., 2005. 424 p.

8. Bagdasar'yan N. G. Kul'turologiya [Culturology]. Moscow, Vysshaya shkola Publ., 2001. 511 p. 
9. Pishchik V.I. Generation: A socio-psychological analysis of mentality. Sotsial'naya psikhologiya i obshchestvo - Social Psychology and Society, 2011, no. 2, pp. 80-88 (in Russian).

10. Strauss W., Howe N. The fourth turning: An American prophecy what the cycles of history tell us about America's next rendezvous with destiny. N. Y., Broadway Books, 1997. $400 \mathrm{p}$.

11. Leont'ev A. N., Sokolova E. E. (ed.) Lektsii po obshchei psikhologii [Lectures on general psychology]. Moscow, Smysl Publ., 2000. 509 p.

12. Van Hiel A., Mervielde I., De Fruyt F. Stagnation and generativity: Structure, validity and differential relationships with adaptive and maladaptive personality. Journal of Personality, 2006, V. 74, Issue 2, pp. 543-574. DOI: 10.1111/j.1467-6494.2006.00384.x

13. Twenge J.M., Campbell S.M. Generational differences in psychological traits and their impact on the workplace. Journal of Managerial Psychology, 2009, V. 23, Issue 8, pp. 862-877. DOI: 10.1108/02683940810904367

14. Gilleard C., Higgs P. Contexts of ageing: class, cohort and community. Cambridge, Polity Press, 2005. 224 p.

15. Andreeva G. M. Sotsial'naya psikhologiya [Social psychology]. Moscow, Aspekt Press Publ., 2001. 384 p.

16. Emel'yanova T. P. The phenomenon of collective feelings in the psychology of large social groups. Social and Economic Psychology, Institute of Psychology, Russian Academy of Sciences, 2016, V. 1, no. 1. Available at: http://soceconom-psychology.ru/engine/documents/document195.pdf (Accessed 16 January 2017).

17. Mid M., Kon I.S. (ed.) Kul'tura imir detstva [Culture and the world of childhood]. Moscow, Nauka Publ., 1988. 429 p.

18. Sochivko D.V. The problem of fragmentation of intergenerational social estrangement of youth in modern Russia. Mir psikhologii - The World of Psychology, 2009, no. 3 (59), pp. 185-194 (in Russian).

19. Zernov D.V. Romantic and pessimistic tendencies in value orientations among young people of various generations. Vestnik of Lobachevsky University of Nizhny Novgorod, 2014, no. 2 (34), pp. 47-53 (in Russian).

20. Lisovskii V.T.Dukhovnyi mir itsennostnye orientatsii molodezhi Rossii [Spiritual world and value orientations among Russian youth]. St. Petersburg, SPbGUP Publ., 2000. 508 p.

21. Pishchik V. I., Gavrilova A.V., Sivrikova N.V. Styles of intergenerational pedagogical interaction between teachers and students of different generational groups. Rossiiskiipsikhologicheskiizhurnal-Russian Psychological Journal, 2016, V. 13, no. 3, pp. 245-264 (in Russian).

22. Rean A. A. A family in the structure of values of young people. Rossiiskii 
psikhologicheskii zhurnal - Russian Psychological Journal, 2017, V. 14, no. 1, pp. 62-78 (in Russian).

23. Poznyakov V.P., Nikulo E. A. Value orientations in entrepreneurs with different levels of a responsible attitude to the participants of business interaction. Psikhologicheskii zhurnal, 2016, V. 37, no. 1, pp. 79-88 (in Russian).

24. Rikel' A. M., Tychinina M.I. Intergeneration differences in the strategies of interpersonal relations. Psychological Research, 2017, V. 10, no. 51, p. 9. Available at: http://psystudy.ru (Accessed 01 October 2017).

25. Isaeva M. I. Crisis and rise generations in W. Strauss and N. Howe's theory. Znanie. Ponimanie. Umenie - Knowledge. Understanding. Skill, 2011, no. 3, pp. 290-295 (in Russian).

26. Toffler A. Future shock [Russ. ed.: Toffler E. Shok budushchego. Moscow, AST Publ., 2008. 560 p.).

27. Inglehart R., Welzel Ch. Modernization, cultural change, and democracy: The human development sequence. Cambridge, Cambridge University Press, 2005. 344 p.

28. Sun J., Wang X. Value differences between generations in China: A study in Shanghai. Journal of Youth Studies, 2010, V. 13, no. 1, pp. 65-81.

29. Tsunokai G., Ksopowa A., Adams M. Racial preferences in Internet Dating: a comparison of four birth cohorts. The Western Journal of Black Studies, 2009, V. 33, no. 1, pp. 1-15.

30. Howe N., Strauss W. Generations: The history of America's future, 1584-2069. New York, William Morrow \& Company, 1991. 538 p. 